JRPB, Vol. 7, No. 2, September 2019, Hal. 185-195

DOI: $10.29303 /$ jrpb.v7i2.128

ISSN 2301-8119, e-ISSN 2443-1354

Tersedia online di http://jrpb.unram.ac.id/

\title{
RANCANG BANGUN DAN UJI KINERJA ALAT PENGERING TEMBAKAU MOLE TIPE EFEK RUMAH KACA (ERK) KONSTRUKSI BAMBU
}

\author{
Design and Performance Test of a Bamboo Constructtion ERK Type \\ Mole Tobacco Dryer
}

\author{
Wahyu K Sugandi ${ }^{1}$, Ahmad Thoriq ${ }^{1}$, Asep Yusuf ${ }^{1}$, Arif Purwonugroho ${ }^{1}$ \\ ${ }^{1}$ Departemen Teknik Pertanian dan Biosistem, Fakultas Teknologi Industri Pertanian, \\ Universitas Padjadjaran, Jalan Raya Bandung-Sumedang km 21, Jatinangor, \\ Sumedang, 45363
}

Email $^{*}$ ): wahyusugandi@gmail.com

Diterima: Juni 2019

Disetujui: September 2019

\begin{abstract}
Currently the drying process of tobacco mole produced in Sukasari District still uses solar energy which is strongly influenced by weather conditions and is very vulnerable to being contaminated by other materials during drying. The drying process using solar energy requires 7-14 days depending on the weather. To speed up the drying process, it is necessary to design a bamboo construction ERK type mole dryer. The purpose of this research is to design and test the performance of ERK type tobacco mole dryer construction, so that it can speed up the drying process of tobacco in large quantities. The research method uses engineering methods through several stages of the activity process, namely: designing ERK type dryers, functional mixtures, structural designs, technical analysis and performance tests. ERK type mole tobacco dryer bamboo construction that has been made has an overall length of $5 \mathrm{~m}$, width of $3 \mathrm{~m}$, and height of $2.5 \mathrm{~m}$. Construction of dryers using betung and tie bamboo, walls as coatings for dryers use 6\% UV plastic. Based on the analysis using Ansys software, it was found that the shear stress was still below the recommended threshold of $20.42 \mathrm{~Pa}$, while the threshold of petung bamboo was $177 \mathrm{MPa}$. In the no-load test using an exhaust fan, the temperature obtained after 24 hours of data collection in the ERK dryer was equal to $14^{\circ} \mathrm{C}-46^{\circ} \mathrm{C}$, while the temperature outside the ERK dryer was $16^{\circ} 4-30.5^{\circ} \mathrm{C}$. Decrease in the water content of tobacco produced by this dryer was $66 \%$ for 5 days, while outside the dryer was $71 \%$ for 14 days. Thermal and drying efficiency was $17.24 \%$ and $55.79 \%$ respectively.
\end{abstract}

Keywords: ERK Dryer, bamboo, design, performance test, Mole Tobacco 


\begin{abstract}
ABSTRAK
Saat ini proses pengeringan tembakau mole yang dihasilkan di Kecamatan Sukasari masih menggunakan energi cahaya matahari yang sangat dipengaruhi oleh kondisi cuaca dan sangat rentan untuk terkontaminasi oleh material lain saat penjemuran. Proses pengeringan menggunakan energi cahaya matahari ini memerlukan waktu 14 - 20 hari tergantung cuaca. Untuk mempercepat proses pengeringan, perlu dilakukan rancangbangun alat pengering tembakau mole tipe ERK konstruksi bambu. Tujuan dari penelitian ini adalah untuk merancangbangun dan melakukan uji kinerja alat pengering tembakau mole tipe ERK konstruksi bambu, sehingga dapat mempercepat proses pengeringan tembakau dalam jumlah besar. Metode penelitian menggunakan metode rekayasa dengan melalui beberapa tahap proses kegiatan yaitu: perancangan alat pengering tipe ERK, rancangan fungsional, rancangan struktural, analisis teknik dan uji kinerja. Alat pengering tembakau mole tipe ERK konstruksi bambu yang telah dibuat memiliki panjang keseluruhan $5 \mathrm{~m}$, lebar $3 \mathrm{~m}$ dan tinggi 2,5 m. Konstruksi alat pengering menggunakan bambu betung dan ikat, dinding sebagai pelapis alat pengering menggunakan plastik UV 6\%. Berdasarkan analisis menggunakan software Ansys didapatkan tegangan pada rangka masih dibawah ambang batas yang disarankan, yaitu sebesar 20,42 Pa, sedangkan ambang batas bambu petung adalah sebesar $177 \mathrm{MPa}$. Pada pengujian tanpa beban menggunakan exaust fan, suhu yang diperoleh setelah pengambilan data selama 24 jam di dalam alat pengering ERK yaitu sebesar $14^{\circ} \mathrm{C}-46^{\circ} \mathrm{C}$ dan sedangkan suhu diluar alat pengering ERK sebesar $16,4-30,5^{\circ} \mathrm{C}$. Penurunan kadar air tembakau yang dihasilkan alat pengering ini sebesar $66 \%$ selama 5 hari, sedangkan diluar alat pengering sebesar $71 \%$ selama 14 hari. Efisiensi termal dan pengeringan alat pengering ini sebesar $55,79 \%$ dan $17,24 \%$.
\end{abstract}

Kata kunci: alat pengering ERK, bambu, rancangbangun, uji kinerja, Tembakau Mole

\section{PENDAHULUAN}

\begin{tabular}{ccc}
\multicolumn{2}{c}{ Tanaman } & tembakau merupakan \\
salah satu & komoditas & unggulan \\
perkebunan & Kabupaten & Sumedang
\end{tabular}

perkebunan di Kabupaten Sumedang. Tembakau yang hasilkan merupakan jenis tembakau mole yang menjadi ciri khas Kabupaten Sumedang yang telah terdaftar pada Indikasi Geografis No. 000000008. Tembakau mole memiliki mutu dan cita rasa khas diantaranya aroma khas wangi, rasa isap enak, dan bebas dari rasa pahit (Dirjen Kekayaan Intelektual, 2011).

Proses pengolahan tembakau mole terdiri atas panen atau pemetikan daun, sortasi daun hijau, pemeraman daun, perajangan, pengeringan dan pengebalan. Proses pengeringan merupakan proses yang menentukan mutu tembakau (Iskandar, dkk. 2017). Saat ini proses pengeringan tembakau mole yang dihasilkan di Kecamatan Sukasari masih menggunakan energi cahaya matahari yang sangat dipengaruhi oleh kondisi cuaca dan sangat rentan untuk terkontaminasi oleh material lain saat penjemuran.

Saat ini banyak pengembangan alat pengering untuk bahan hasil pertanian yang dapat ditemukan. Diantaranya alat pengering kolektor surya (Supriyadi, 2005), pengering menggunakan tenaga listrik (oven) (Wadli, 2005), dan pengering vakum. Namun pengeringpengering tersebut memerlukan modal yang besar untuk pengadaan dan pengoperasiannya. Disisi lain teknik pengeringan tersebut belum tentu dapat diterima oleh petani sekitar, karena dalam pengoperasiannya yang cukup kompleks dan membutuhkan tenaga ahli.

Pemilihan pengeringan jenis 
bangunan berdinding transparan dengan mekanisme efek rumah kaca adalah untuk tetap mengakomodasi pengeringan alamiah yang memanfaatkan panas radiasi surya harian yang melimpah di negara tropis seperti Indonesia. Keunggulan sistem ini dari jenis pengeringan konvensional adalah pemanfaatan luasan lahan yang relatif sempit dan terhindar dari gangguan alam seperti hujan dan angin. Pengering ini dianggap cukup baik dari segi performansi karena dalam pengoperasiannya tidak memerlukan keahlian dan pengetahuan khusus.

Masalah utama sistem konvensional ini adalah adanya perubahan cuaca yang tidak menentu seperti hujan yang turun mendadak sehingga para petani mesti memindahkan sasag ketempat yang lebih teduh, selain itu juga daya serap panas kurang oprimal Oleh sebat itu perlu adanya rancangan alat pengering tembakau sesuai dengan karakteristik fisik bahan yang dikeringkan.

Penelitian mengenai pengeringan telah banyak dilakukan diantaran oleh Suryadi (2017) mengenai pengeringan tipe Fluidized Bed, Murad, dkk., (2015) mengenai pengeringan kopra putih, Putra, dkk., (2018) mengenai pengeringan silinder vertikal.

Rancangan yang akan dibangun terbuat dari bambu, hal ini dikarenakan bambu dapat diperoleh dengan mudah di Desa Genteng, harganya lebih murah, desain sederhana dan kemampuan mengeringkan produk dengan kapasitas 60 sasag atau $50 \mathrm{~kg}$.

\section{METODOLOGI}

Penelitian ini dilaksanakan pada bulan Juni sampai dengan Desember 2018. Perancangan, pembuatan alat pengering dan pengujian dilakukan di Desa Genteng, Kecamatan Sukasari, Kabupaten Sumedang. Pembuatan prototype dan pengujian dilakukan di Laboratorium Material, Fakultas Matematika dan Ilmu Pengerahuan Alam, Universitas Padjadjaran, Jatinangor.

Alat yang digunakan diantaranya termometer dan thermohygrometer untuk mengukur suhu di dalam alat dan prototype, LUX meter untuk mengukur intensitas cahaya matahari, spektrofotometer UV-Vis untuk mengetahui nilai transmivitas dan absorbansi plastik UV, Laptop ASUS K43SD untuk pengolahan data dan pembuatan rancangan dalam bentuk 3D menggunakan software AutoCAD 2013 dan kamera CANON 60D untuk pengambilan gambar selama penelitian berlangsung.

Adapun bahan yang digunakan dalam penelitian ini diantaranya bambu untuk pembuatan konstruksi rangka alat pengering tembakau mole, pengikat bambu tersebut menggunakan paku dan tali majun untuk memperkokoh konstruksi alat pengering tersebut, bahan pembuatan prototype menggunakan kayu kaso/ reng untuk pembuatan rangka prototype-nya, plastik UV (14\%, 8\%, 6\%), dan tembakau mole merah sebagai bahan yang akan diuji. 
Prosedur penelitian yang dilakukan disajikan pada Gambar 1.

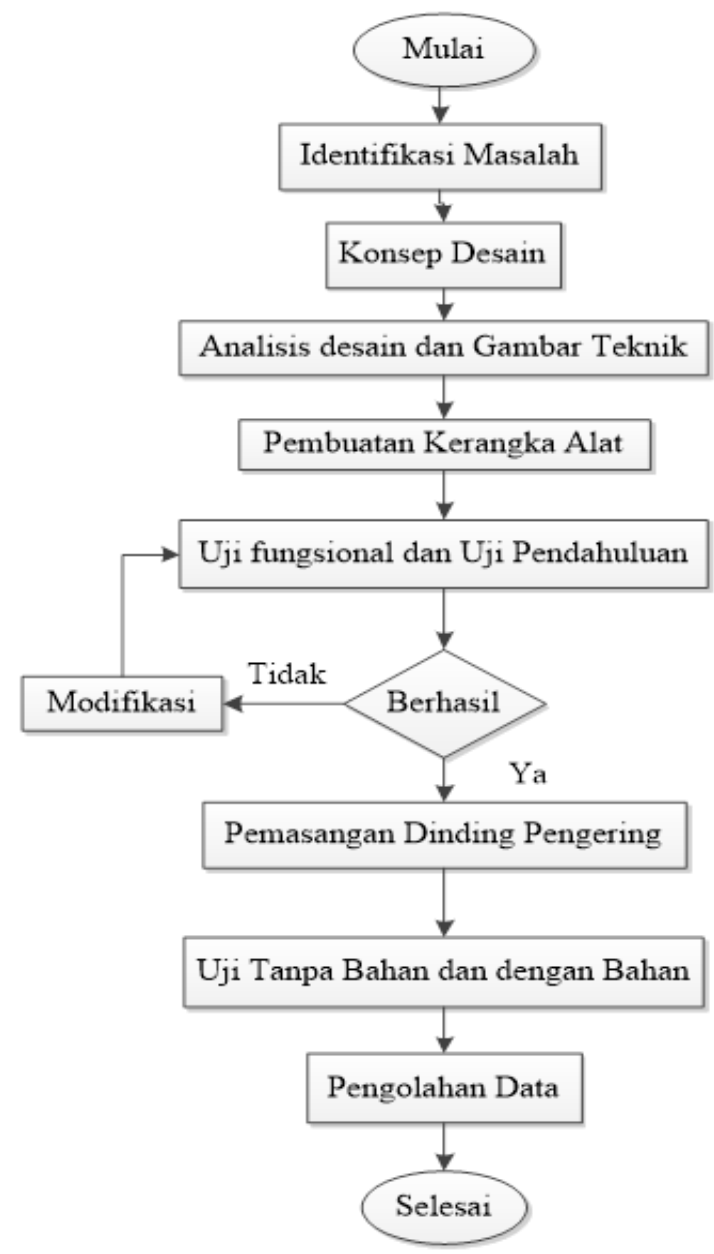

Gambar 1. Diagram alir penelitian

Adapun tahapan-tahapan penelitian ini sebagai berikut:

\section{Identifikasi Masalah}

Identifikasi masalah dilakukan dengan survei dan wawancara langsung meliputi proses pengolahan daun tembakau, hasil pengeringan dengan menggunakan cara yang tradisional, lamanya waktu pengeringan serta kapasitas produksi pengeringan tembakau mole. Hasil pengamatan kemudian dijadikan pertimbangan dalam merancang alat.

\section{Konsep Desain}

Alat yang dirancang diharapkan mampu mengeringkan tembakau dengan optimal kapasitas 40 sasag dengan waktu pengeringan kurang dari seminggu.

\section{Analisis Teknikan Gambar Teknik}

Perhitungan analisis teknik ini merupakan dasar yang akan menentukan dimensi alat yang akan digambarkan pada gambar teknik yaitu meliputi desain dinding, desain rangka dan desain atap. Setelah diperoleh perhitungan analasis teknik, semua hasil perhitungan dituangkan dalam bentuk gambar teknik untuk mempermudah pembuatan alat.

\section{Pembuatan Kerangka Alat}

Pembuatan konstruksi alat ini memerlukan bambu, paku dan tali majun. Dimana bambu disini sebagai rangka dari alat yang akan dirancang, sedangkan paku dan tali majun sebagai pengikat dari bambu-bambu yang disusun.

\section{Uji Fungsional}

Adapun uji pendahuluan ini meliputi pengujian plastik UV dan analisis teknik yang dilakukan dengan 2 tahap, yaitu dengan software Ansys dan perhitungan manual.

Pengujian plastik UV dilakukan dengan membuat prototype dengan ukuran panjang $50 \mathrm{~cm}$, lebar $50 \mathrm{~cm}$, dan tinggi 60 $\mathrm{cm}$, membuat 3 buah prototype dan memasang dinding prototype tersebut dengan plastik $U V$ yang keburamannya berbeda $(14 \%, 8 \%$ dan 6\%). Pengujian dilakukan di lahan kosong milik petani di Desa Genteng. Pengukuran suhu di dalam prototype menggunakan termometer yang diikat menggantung di tengah, pengukuran dilakukan selama 11 jam mulai dari pukul 07.00 WIB sampai dengan 17.00 WIB. Pengamatan suhu dilakukan setiap 1 jam sekali.

Pengujian

selanjutnya menggunakan alat spektofotometer, bertujuan untuk mengetahui reflektansi dan transmitansi cahaya pada plastik UV $14 \%$, 8\%, dan 6\%. Hal tersebut untuk menentukan plastik UV dengan kadar keburaman berapa persen yang cocok untuk dinding alat pengering tembakau mole efek rumah kaca itu.

Berikut cara menguji plastik UV menggunakan spektrofotometer $U V$-Vis : 
1. Diaktifkan alat spektofotometer $\mathrm{UV} / \mathrm{Vis}$

2. Disiapkan bahan plastik UV dengan kadar keburaman 14\%, $8 \%$ dan $6 \%$.

3. Diletakkan sampel pada penjepit sampel yang berada pada bagian yang ada pada spektrofotometer UV-Vis.

4. Ditembakkan sinar dengan gelombang 200-780nm.

5. Hasil akan keluar berupa grafik abrsorbansi dan transmitansi dari bahan.

Gambar dan bagian-bagian dari alat spektofotometer UV-Vis tersedia pada Gambar 2.

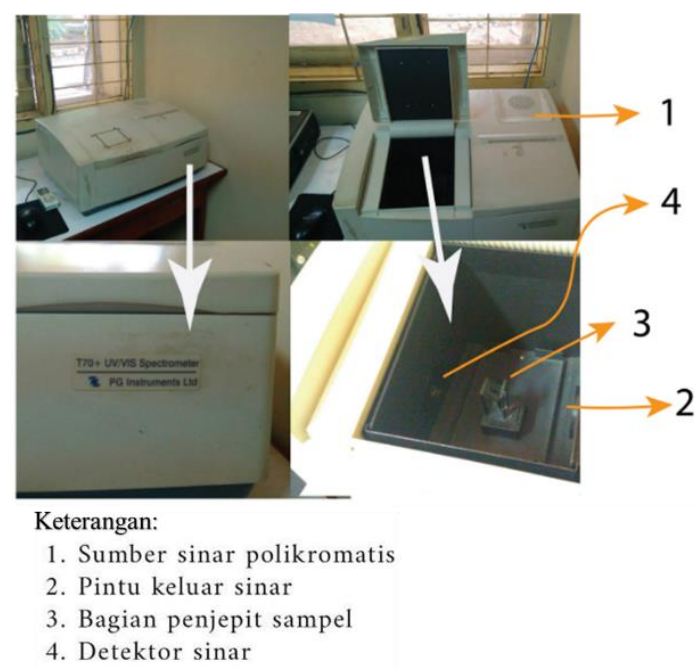

Gambar 2. Spektrofotometer UV-Vis

Pengujian selanjutnya menggunakan software Ansys dan dengan metode perhitungan momen. Pada pengujian menggunakan software Ansys, yaitu dengan memasukan parameter-parameter yang akan dihitung seperti massa jenis bambu, dimensi dari bambu, dan tensile strenght.

\section{Pemasangan Dinding Plastik}

Pemasangan dinding dilakukan setelah memperoleh hasil dari pengujian pendahuluan ketiga plastik UV dan hasil dari pengujian menggunakan spektofotometer UV-Vis. Karena jika salah memasang plastik UV, maka hasil yang diperoleh belum tentu maksimal.

\section{Uji Tanpa Bahan dengan Bahan}

Uji tanpa beban dilakukan dengan tujuan untuk mengetahui kondisi suhu dan $\mathrm{RH}$ di dalam pengering efek rumah kaca, dengan membandingkan suhu dan $\mathrm{RH}$ di dalam pengering dengan di luar alat pengering selama 24 jam. Sedangkan uji dengan beban dimaksudkan untuk mengetahui kadar air bahan yang teruapkan, laju pengeringan dan efisiensi pengeringan pada alat pengering efek rumah kaca ini.

\section{Pengolahan Data}

Pengolahan data dalam penelitian ini untuk analisis kekuatan rangka mengacu pada perhitungan mekanika teknik dan untuk analisis pengeringan tembakau mengacu pada Wulandani (2005). Parameter yang dianalisis antara lain kadar air produk, laju pengeringan, bobot kering bahan, dan pindah panas dalam proses pengeringan.

Analisa kadar air produk dilakukan dengan menggunakan persamaan 1 .

Kadar air $(\% b k)=\frac{\left(W_{0}+W_{1}-W_{2}\right)}{W_{1}} \times 100 \%$.. (1) Keterangan:

$$
\begin{array}{ll}
W_{0} & =\text { massa cawan }(\text { gram }) \\
W_{1} & =\begin{array}{l}
\text { massa padatan pada } \\
\text { tembakau (gram) }
\end{array} \\
W_{2} & =\begin{array}{l}
\text { massa tembakau yang telah } \\
\text { dikeringkan (gram) }
\end{array}
\end{array}
$$

Laju pengeringan dapat dianalisis dengan menggunakan persamaan berikut.

$$
\begin{aligned}
& \dot{\mathrm{m}}_{u a p}=\frac{\Delta \mathrm{mt}}{t_{u a p}} \\
& \dot{\mathrm{m}}_{\text {uap }}=\text { laju penguapan }(\mathrm{kg} / \mathrm{jam}) \\
& \Delta \mathrm{mt}=\text { pengurangan massa } \\
& t_{\text {uap }}=\begin{array}{l}
\text { tama waktu penguapan } \\
\text { (detik) }
\end{array}
\end{aligned}
$$

Untuk menentukan bobot kering suatu bahan, penimbangan dilakukan setelah bobot bahan tersebut tidak berubah lagi selama proses pengeringan. Pengeringan 
dilakukan dengan menggunakan suhu $105^{\circ} \mathrm{C}$ minimal selama lima jam. Analisis perhitungan pada pindah panas terdiri dari mencari kalor untuk memanaskan bahan (persamaan 3), menganalisis kalor dari sumber panas yang masuk (persamaan 4), dan mencari efisiensi pengeringan pada alat pengering (persamaan 5).

$$
\begin{aligned}
& \mathrm{Q}_{1}=\mathrm{m}_{\mathrm{o}} \times \mathrm{C}_{\text {produk }} \times\left(\mathrm{T}_{2}-\mathrm{T}_{1}\right) \\
& \mathrm{Q}_{\mathrm{s}}=3,6 \times \mathrm{I}_{\mathrm{g}} \times \mathrm{A}_{\mathrm{p}} \times \tau \times \mathrm{t} \ldots \ldots \ldots \ldots . . . \\
& \eta_{\text {pengeringan }}=\frac{\boldsymbol{Q}_{T}}{\boldsymbol{Q}_{\boldsymbol{s}}} \times 100 \% \ldots \ldots \ldots \\
& \text { Keterangan: }
\end{aligned}
$$

\begin{tabular}{|c|c|c|}
\hline & & \\
\hline $\mathrm{Q}_{1}$ & $=$ & $\begin{array}{l}\text { panas } \\
\text { meningkatkan } \\
\text { bahan }\end{array}$ \\
\hline $\mathrm{m}_{\mathrm{o}}$ & $=$ & massa awal \\
\hline $\mathrm{T}_{2}$ & $=$ & suhu akhir pemanasan \\
\hline $\mathrm{T}_{1}$ & $=$ & suhu awal pemanasan \\
\hline$Q_{s}$ & $=$ & kalor dari sumber panas \\
\hline $\mathrm{Q}_{\mathrm{T}}$ & $=$ & panas total \\
\hline$\eta_{\text {pengeringan }}$ & $=$ & efisiensi pengeringan \\
\hline
\end{tabular}

\section{HASIL DAN PEMBAHASAN}

\section{Uji Pendahuluan}

a. Pengujian Plastik UV

Uji pendahuluan ini membutuhkan waktu 8 jam lamanya, hal ini dipilih karena waktu tersebut yang digunakan petani untuk mengeringkan tembakau seperti biasanya. Pengujian plastik UV yang menggunakan prototype diperoleh hasil seperti terlihat pada Gambar 3.

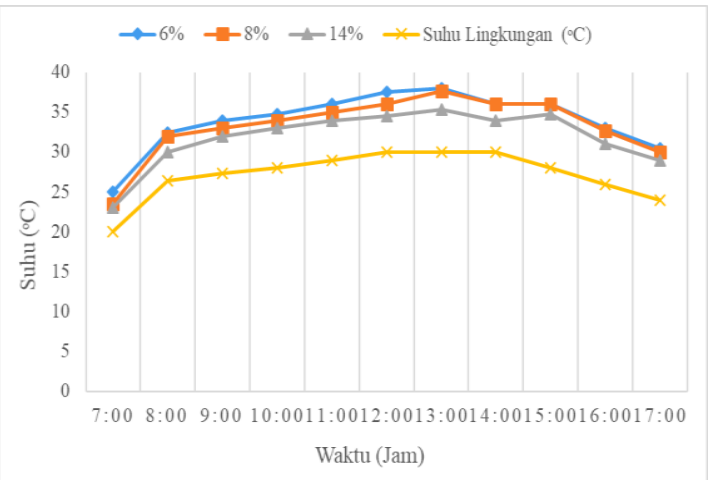

Gambar 3. Grafik Hubungan Antara Suhu dan Waktu pada Pengujian Plastik UV Menggunakan Prototype

Hasil dari percobaan tersebut, plastik yang memperoleh panas yang cukup bagus dihasilkan oleh plastik UV $6 \%$ dan $8 \%$. Hasil keduanya tidak begitu jauh selisihnya, dengan rata-rata panas yang diperoleh diantara keduanya yakni $33,92^{\circ} \mathrm{C}$ dan $33,26^{\circ} \mathrm{C}$, sedangkan untuk plastik UV $14 \%$ suhu rata-ratanya yaitu $31,88^{\circ} \mathrm{C}$. Dari ketiga jenis plastik UV yang menghasilkan suhu panas yang paling baik yaitu plastik UV 6\%. Berdasarkan hasil percobaan tersebut, ketiga plastik UV menghasilkan panas yang lebih tinggi dibandingkan dengan suhu lingkungan sekitar.

Berdasarkan hasil yang telah diuji melalui spektrofotometer UV-Vis, hasil menunjukan plastik UV 6\% memiliki nilai absorbansi pada sinar UV yang lebih kecil dan dapat mentransmisikan cahaya jauh lebih baik dibandingkan plastik UV lainnya. Hal tersebut diperkuat dari pengujian menggunkan prototype yang menghasilkan plastik UV 6\% lebih panas dibandingkan palstik UV $8 \%$ dan $14 \%$. Berdasarkan dari hasil uji pendahuluan plastik UV 6\% dipilih sebagai dinding pelapis alat pengering tembakau mole tipe ERK.

b. Analisis Teknik

Analisis teknik untuk alat pengering ERK ini dilakukan dengan menggunakan software ansys (Gambar 4).

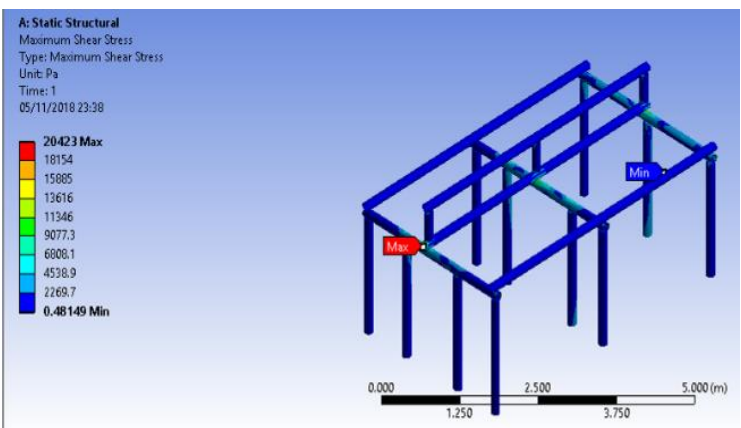

Gambar 4. Hasil Analisis Teknik Menggunakan Software Ansys

Berdasarkan hasil Ansys yang terlihat pada Gambar 4, terlihat indikator warna pada rangka alat pengering ERK, warna tersebut menunjukan bahwa warna merah menunjukan tegangan penuh yang 
terjadi pada alat pengering tersebut dan warna biru untuk menunjukan tegangan yang paling ringan pada alat tersebut. Tegangan yang paling tinggi terdapat pada titik tengah di kuda-kuda bagian depan alat pengering sebesar 20,423 $\mathrm{Pa}$, sedangkan didalam ISO 22157 tegangan maksimum (Maks. Tensile Strength) dari bambu betung ini sebesar $177 \mathrm{MPa}$, hal tersebut membuktikan bahwa tegangan yang diterima pada alat pengering bisa dikatakan aman.

c. Analisis Pindah Panas Pada Ruang Pengering

Efisiensi pengeringan dan termal yang dihasilkan dari pengujian menggunakan exhaust fan sebesar 17,24 $\%$ dan $44,85 \%$.

Tabel 1. Penggunaan energi dan efisiensi pengering

\begin{tabular}{ll}
\hline \multicolumn{1}{c}{ Parameter } & \multicolumn{1}{c}{ Hasil } \\
\hline $\begin{array}{l}\text { Energi surya yang diterima pengering }(\mathrm{kJ}) \\
\text { Panas untuk meningkatkan suhu bahan }\end{array}$ & 168012,59 \\
$(\mathrm{~kJ})$ & 2707,47 \\
Panas untuk menguapkan air bahan & \\
$(\mathrm{kJ} / \mathrm{kg})$ & 1890,75 \\
Efisiensi pengeringan $(\%)$ & 17,24 \\
Efisiensi Thermal (\%) & 55,79 \\
\hline
\end{tabular}

Tabel 1 menunjukkan sebaran pemanfaatan energi. Energi yang diterima sebesar 168012,59 kJ digunakan untuk meningkatkan suhu bahan sebesar $2707,47 \mathrm{~kJ}$ dan menguapkan suhu bahan sebesar 1890,75 kJ. Selama pengeringan, jumlah massa uap air yang di buang sebesar 0,788 gr dari kadar air awal 84,3\% sampai $14,5 \%$.

\section{Alat Pengering Hasil Rancang Bangun}

Hasil dari peracangan kerangka alat pengering tembakau efek rumah kaca ini (Gambar 5). Komponen fungsional alat pengering tembakau mole tipe ERK ini terdiri atas rangka, rak, atap, dinding, dan ventilasi. Berbeda dengan ERK tipe lain, ERK yang dirancang berbahan dasar dari bambu untuk rangkanya. Adapun alat pengering ini posisinya melintang dari selatan ke utara, hal ini dikarenakan agar alat pengering mendapatkan cahaya matahari secara optimal dari pagi hingga sore. Walaupun rak paling bawah tidak memperoleh cahaya yang optimal dibandingkan rak tengah dan atas.

\section{Kinerja Alat Pengering}

Mekanisme kerja alat ini dengan memanfaatkan energi cahaya matahari yang masuk, dalam alat ini terdapat 6 rak $(2 \times 3$ tingkat rak) untuk menempatkan sasag yang berisikan tembakau yang sudah diiris tipis. Pada setiap rak-nya dapat diisi dengan 10 sasag. Cahaya matahari yang masuk akan tersimpan dalam alat tersebut, dimana pada alat tersebut dilapisi oleh plastik $U V$ yang memungkinkan cahaya matahari yang masuk akan terjebak sebagian dalam alat tersebut. Hal tersebut akan menghasilkan suhu yang lebih panas dibandingkan suhu diluar alat. Performansi pengering ERK dan lingkungan terdapat pada Tabel 2 . 

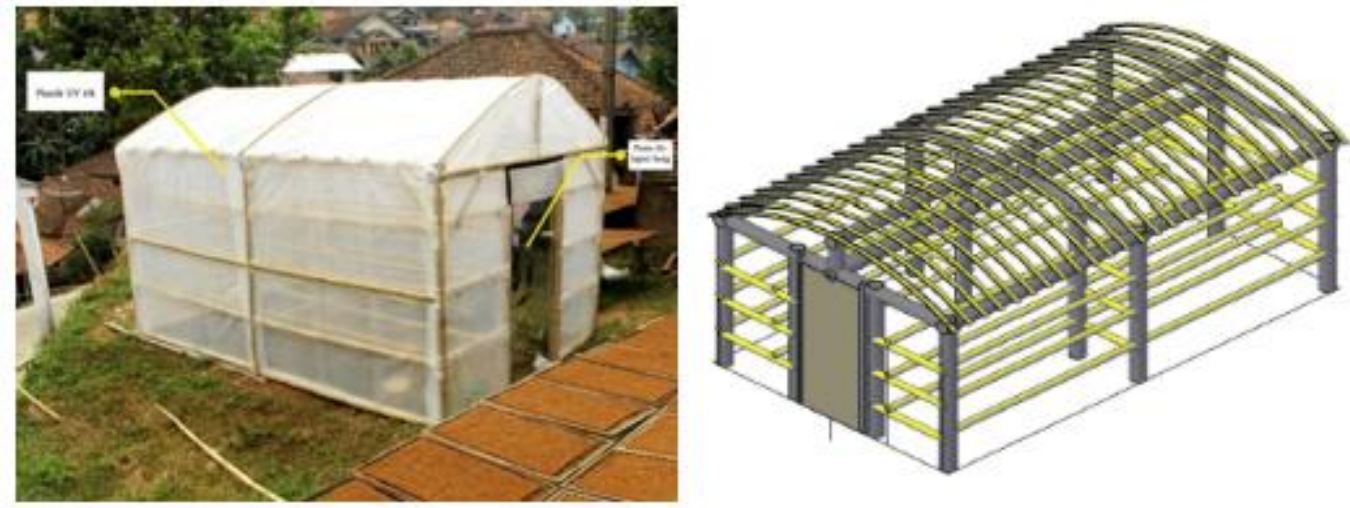

Gambar 5. Alat pengering tembakau efek rumah kaca

Tabel 2. Tabel Performansi Alat Pengering ERK dan Lingkungan

\begin{tabular}{llcc}
\hline \multirow{2}{*}{ No. } & Keterangan & Ruang Pengering & Hasil \\
\hline 1 & Massa Awal Tembakau (kg) & 0,97 & 0,97 \\
2 & Massa Akhir Tembakau (kg) & 0,207 & 0,265 \\
3 & Kadar Air Awal Tembakau (\%bb) & 84,3 & 87,7 \\
4 & Kadar Air Akhir Tembakau (\%bb) & 14,5 & 16,7 \\
5 & Lama Pengeringan (hari) & 5 & 14 \\
6 & Laju Pengeringan (\%bb/jam) & 16,65 & 12,1 \\
7 & Suhu Pengering $\left({ }^{\circ} \mathrm{C}\right)$ & 51,5 & 32 \\
8 & Efisiensi Pengering (\%) & 17,24 & 0,32 \\
& & & \\
\hline
\end{tabular}

\section{a. Uji Tanpa Bahan}

Uji tanpa bahan dilakukan dengan menggunakan exhaust fan dan ventilasi. Pada saat penggunaan exhaust fan, suhu terendah pada semua rak terjadi pada pukul 05.00 WIB dengan rata-rata $15,5^{\circ} \mathrm{C}$. Mulai pukul 07.00 WIB mulai memperlihatkan perubahan suhu, hal ini karena sinar matahari sudah mulai menembus plastik UV pada alat pengering. Kenaikan suhu ini berlanjut hingga pukul $12.00 \mathrm{WIB}$, rata-rata suhu dari semua rak ketika pukul 12.00 WIB yaitu $43,867^{\circ} \mathrm{C}$. Memasuki pukul 13.00 WIB suhu mengalami penurunan, hal ini diakibatkan dari faktor cuaca yang berawan dan cerah kembali pada pukul 14.00 hingga pukul 16.00 WIB.

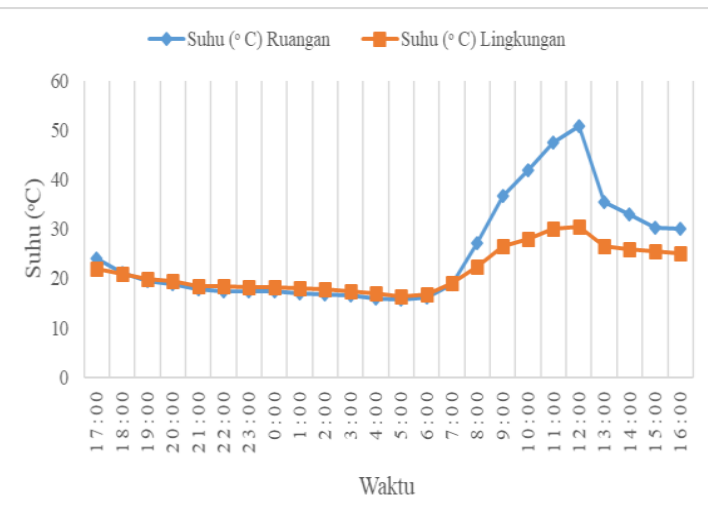

Gambar 6. Grafik Perbandingan Suhu Lingkungan dengan Ruangan pada Uji Tanpa Bahan (dengan exhaust fan)

Gambar 6 menunjukan bahwa perbedaan yang cukup signifikan pada waktu pagi hingga siang hari. Suhu pada ruangan pengering naik melonjak ketika memasuki pukul 07.00 WIB, suhu naik hingga pada pukul 12.00 WIB dengan angka tertinggi yaitu $50,8^{\circ} \mathrm{C}$. Setelah jam 12.00 WIB temperatur dalam alat pengering mengalami penurunan hingga pukul 16.00 WIB. Sedangkan untuk suhu 
diluar ruangan atau bisa disebut suhu lingkungan mendapat nilai tertinggi hanya $30,5^{\circ} \mathrm{C}$ pada pukul $12.00 \mathrm{WIB}$. Dari kedua grafik ini terdapat perbedaan yang cukup signifikan mulai pada pukul 07.00 hingga 14.00 WIB.

Pengujian dengan menggunakan ventilasi mengalami kenaikan suhu terjadi pada pukul 07.00 hingga pukul 12.00 WIB, suhu tertinggi terjadi pada pukul 12.00 dengan perolehan suhu dari semua rak yakni $41,59^{\circ} \mathrm{C}$, dari keseluruhan rak ada 1 titik yang menghasilkan suhu tertinggi diantara yang lain yakni $44,5^{\circ} \mathrm{C}$ pada rak 3 di titik nomor 1 . Hal ini disebabkan oleh posisi rak tersebut yang berada paling atas dan dekat dengan atap yang memungkinkan memperoleh panas lebih tinggi dibandingkan rak-rak yang lain.

Penurunan suhu terjadi ketika sudah melewati pukul 12.00 , penurunan ini berlangsung hingga pukul 06.00. Suhu terendah terjadi pada pukul 05.00 dengan rata-rata $16,33^{\circ} \mathrm{C}$, lalu untuk suhu terendah dari tiap-tiap titiknya terjadi pada rak 2 dengan titik nomor 1 dengan perolehan suhu $15^{\circ} \mathrm{C}$.

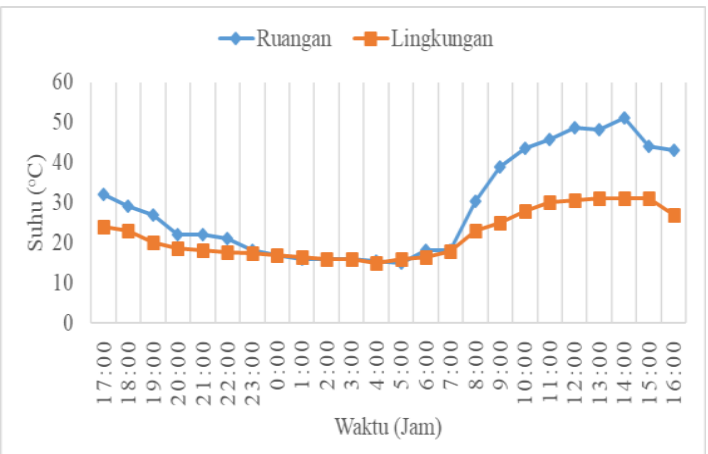

Gambar 7. Grafik Perbandingan Suhu Lingkungan dengan Ruangan pada Uji Tanpa Bahan (dengan ventilasi)
Suhu lingkungan dan ruangan yang tersaji pada Gambar 7, menunjukan perbedaan yang cukup signifikan pada waktu pagi hingga siang hari. Suhu pada ruangan pengering naik melonjak ketika memasuki pukul 07.00 WIB, suhu naik hingga pada pukul 12.00 WIB dengan angka yaitu $48,7^{\circ} \mathrm{C}$, suhu sempat turun ketika pukul 13.00 yang kemudian naik kembali di pukul 14.00 WIB dengan suhu $51,1^{\circ} \mathrm{C}$. Setelah jam 14.00 WIB temperatur dalam alat pengering mengalami penurunan hingga keesokan harinya. Sedangkan untuk suhu diluar ruangan atau bisa disebut suhu lingkungan mendapat nilai tertinggi hanya $31^{\circ} \mathrm{C}$.

b. Pemilihan Perlakuan untuk Uji Kinerja Berdasarkan hasil yang diperoleh setelah pengamatan dapat dilihat pada Gambar 8. Pola grafik menunjukan suhu ruang pengering selama 24 jam dengan berbeda perlakuan dan berbeda hari pengujian. Pola grafik yang menunjukan suhu tertinggi yaitu pada perlakuan exhaust fan, akan tetapi pada perlakuan exaust fan terjadinya penurunan suhu yang drastis pada $13.00 \mathrm{WIB}$, hal tersebut terjadi karena cuaca berawan pada saat pengujian, sedangkan pada perlakuan menggunakan ventilasi cuacanya cerah pada saat pengujian. 


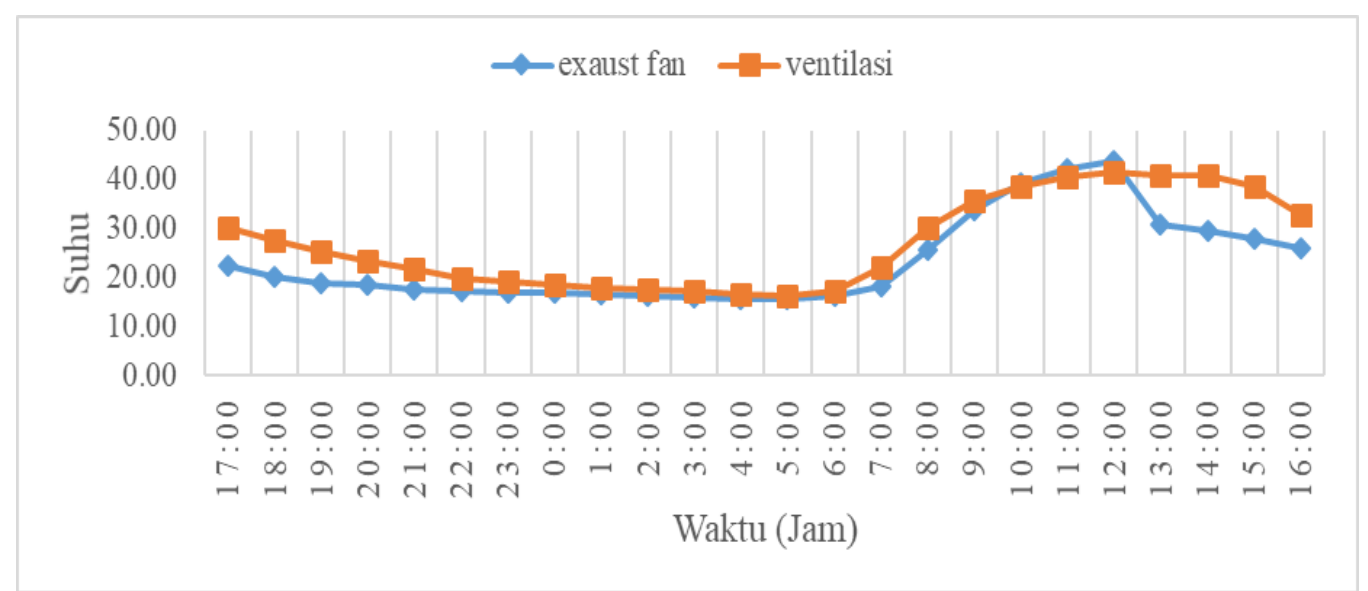

Gambar 8. Grafik Suhu dengan Ventilasi dan Exhaust Fan

Pada perlakuan menggunakan ventilasi suhu yang dihasilkan ruang pengering cenderung stabil pada siang hari. Namun untuk uji dengan sampel, perlakuan yang dipilih yaitu perlakuan dengan exhaust fan. Perlakuan menggunakan exhaust fan dipilih karena suhu yang diperoleh ketika cuaca cerah yaitu $43,86^{\circ} \mathrm{C}$, sedangkan perlakuan menggunakan ventilasi $41,63^{\circ} \mathrm{C}$.

c. Uji dengan Sample menggunakan Exhaust Fan

Uji kinerja alat pengering ERK dengan menggunakan exhaust fan dan menggunakan 11 buah sampel yang berisikan tembakau mole beureum (merah). Uji kinerja ini dilaksanakan mulai dari pukul 07.00 WIB hingga 16.00 WIB, waktu tersebut dipilih berdasarkan kebiasaan petani tembakau yang menjemur tembakaunya pada waktu tersebut, hal tersebut diperkuat dari hasil uji pendahuan alat pengering ERK dengan jangka waktu 24 jam lamanya. Hasil dari uji pendahuluan tersebut diperoleh waktu ideal untuk penjemuran tembakau ditinjau dari suhu yang terdapat pada alat pengering ERK, dimana hasil tersebut menunjukan bahwa mulai dari pukul 07.00 hingga 16.00 panas yang dihasilkan di atas $25^{\circ} \mathrm{C}$.

Efisiensi Pengeringan dihitung dengan cara membandingkan jumlah energi yang digunakan untuk menguapkan kandungan air bahan dengan jumlah energi yang digunakan untuk memanaskan udara pengering, dinyatakan dalam persen sebagaimana pada persamaan 5. Efisiensi pengeringan dari pengujian yang telah dilakukan yaitu sebesar 17,24\%. Semakin tinggi nilai efisiensi pengeringan maka performansi alat pengering tersebut semakin baik.

\section{KESIMPULAN}

Kesimpulan yang dapat diperoleh dari penelitian ini adalah sebagai berikut:

1. Rancang bangun alat pengering tembakau mole tipe ERK dengan konstruksi bambu dengan dinding menggunakan plastik UV 6\% dipilih berdasarkan hasil pengujian plastik UV dengan prototype dan spektrofotometer UV-Vis; dan alas dari alat pengering ini menggunakan plastik mulsa untuk memaksimalkan panasnya.

2. Laju pengeringan dari sampel yang di dalam ruang pengering sebesar $12,104 \%$ perjam berlangsung selama 5 hari atau 45 jam dalam waktu pengeringan, sedangkan laju pengeringan pada sampel di luar ruang pengering sebesar $9,51 \%$ perjam pengeringan berlangsung selama 14 hari lamanya.

3. Efisiensi pengeringan dari pengujian yang telah dilakukan yaitu sebesar $17,24 \%$ dan efisiensi termal sebesar $55,79 \%$. 
DAFTAR PUSTAKA

Direktorat Jenderal Kekayaan Intelektual. (2011). Masyarakat Perlindungan Indikasi Geografis Tembakau Kabupaten Sumedang. Buku Persyaratan Indikasi Geografis 000 000 008. Jakarta.

Iskandar, J., Iskandar, B.S., Azril, dan Partasasmita, R. (2017). The practice of farming, processing and trading of tobacco by Sukasari people of Sumedang District, West Java, Indonesia. Universitas Padjadjaran. Sumedang.

Murad, Rahmat, dan Putra, G.M.D. (2015). Pengeringan Lapis Tipis Kopra Putih Menggunakan Oven Pengering. Jurnal Ilmiah Rekayasa Pertanian dan Biosistem. Vol. 3, No. 2.

Nelwan, L.O., Wulandani, D., Paramawati, R., dan Widodo, T.W. (2007). Rancang Bangun Alat Pengering Efek Rumah Kaca (ERK)-Hybrid dan In-Store Drying (ISD) Teritegrasi untuk Biji-Bijian. Laporan Hasil Penelitian. Institut Pertanian Bogor bekerjasama dengan Badan Penelitian dan
Pengembangan Pertanian, Bogor.

Putra, M.A., Sandi, A., Cicih, S., Tamrin, T. (2018). Uji Kinerja Alat Pengering Silinder Vertikal Pada Proses Pengeringan Jagung (Zea mays ssp. Mays). Jurnal Teknik Pertanian Lampung. Vol. 7, No. 2.

Supriyadi, A. (2005). Uji Performansi Kolektor Surya Pelat Datar dan Pelat Gelombang dengan Variasi Jarak Dua Kaca Penutup. J Teknik Vol. 14: 59-65.

Suryadi, Sukmawaty, dan Putra, G.M.D. (2017). Scale Up Dan Uji Teknis Alat Pengering Tipe Fluidized Bed. Jurnal Ilmiah Rekayasa Pertanian dan Biosistem. Vol. 5, No. 2. DOI: https://doi.org/10.29303/jrpb.v5i2.6 $\underline{0}$.

Wadli. (2005). Kajian Pengeringan Rumput Laut Menggunakan Alat Pengering Efek Rumah Kaca. Tesis. Sekolah Pasca Sarjana. IPB. Bogor.

Wulandani, D. (2005). Kajian Distribusi Suhu, RH dan Aliran Udara Pengering untuk Optimasi Disain Pengering Efek Rumah Kaca. PhD Thesis. Sekolah Pasca Sarjana. Institut Pertanian Bogor, Bogor. 